\title{
PRODUCTION OF SCALE IN REGIONAL HYDROPOLITICS: AN ANALYSIS OF LA PLATA RIVER BASIN AND THE GUARANI AQUIFER SYSTEM IN SOUTH AMERICA
}

\begin{abstract}
This article analyses the production of scale in the La Plata River Basin and Guarani Aquifer System within regional hydropolitics in South America. We argue that different political and ecological scales acquire prominence according to the national political goals at stake, reproducing multi-scalar politics within and beyond South America. To support this argument, this article presents a literature review on the concept of scale in geography that explores the production of, and interaction among scales. The article then takes a historical approach to the evolving scales associated with the cases of the La Plata River Basin and Guarani Aquifer System to show how Brazil exerts hydropolitical regional hegemony through the construction of infrastructure and signing of agreements and treaties. Rather than a simple case of conflict or cooperation over water resources, these episodes represent a continuum of political interactions engendered by specific political goals and involving different social actors.
\end{abstract}

KEYWORDS: La Plata, hydropolitics, river basin, scales, Guarani Aquifer System.

\section{HIGHLIGHTS}

- This article explores convergences between the concept of scale in human and physical geography.

- It examines Brazil's exertion of hydro-hegemonic power in South America.

- It contributes to assessments of water politics in South America via a production of scale approach.

- The article analyses the array of social interactions to produce hydropolitical scales. 


\section{INTRODUCTION}

The effects of hydropolitical interactions between regional powers within La Plata River Basin (LPRB) and the Guarani Aquifer System (GAS) have been studied through different disciplinary lenses. However, an approach combining hydropolitics and human geography specifically the production of scale - is still lacking. Moreover, the contribution of a geographical perspective is needed to emphasize the role of spatiality of social actors and how they frame the area, which is a frequent target of international water politics. Spatial frames, such as scales, include, exclude and enhance participants more relevant in hydropolitics. Relevant research has been conducted on this region adopting security complex theory (Queiroz, 2012a; 2012b), examining its institutional architecture (Vilar, Ribeiro, Sant'Anna, 2018), and approaches from law (Gilman et al., 2008; Castillo, 2011; Pochat, 2011), while initial studies on water governance and hydropolitics have also been conducted either in LPRB and GAS (Sant'Anna, 2015; Villar, 2015; Hussein, 2016, 2018). However, research is still lacking regarding the contribution of human geography and of the production of scales debate.

The first contribution of this article is theoretical and to the literature of hydropolitics, specifically through a discussion of the different ways in which scale is produced and its relation to the construction of a regional arena for hydropolitics. In particular, this article argues that there is a need to examine scale in hydropolitics: how scale is constructed, by whom, why, and its implications for regional hydropolitical dynamics. This contribution is supported by analysis of the production of scale in LPRB and GAS, which reveals the different ways in which the different riparian countries and stakeholders constructed scales at different times in order to shape regional hydropolitics during the $20^{\text {th }}$ century. The second original contribution of this article is empirical, and comes from applying the conceptual 
framework that draws from hydropolitics and human geography to the region for the first time. We argue that depending on the national political goals at stake, different political and ecological scales acquire prominence, fostering multi-scalar politics within and beyond South America.

These cases were chosen as case studies as LPRB represents the second largest surface for water resources in South America, and the GAS is the biggest unified groundwater aquifer in the world. Moreover, they are situated within the most economically and populated region of South America, stressing their relevance to regional and national issues. It is important to stud these two cases together as they are connected by the infiltration and discharge paths connecting the LPRB surface water and GAS groundwater.

The first section of this article discusses the concept of scale in human geography and ecology. The understanding that emerges is that elements from both conceptualizations are key to assess how river basins are used to compose transboundary water governance, structuring distinct `river basin trajectories` (Molle and Wester, 2009). The second section presents the empirical cases identifying three key themes: the production of the regional scale; the role of treaties in shaping the LRBP and; the emergence of environmental concerns and cooperation on different scales. Finally, the article ends by discussing the contributions of these different themes to the production of hydropolitical scale in South America. 


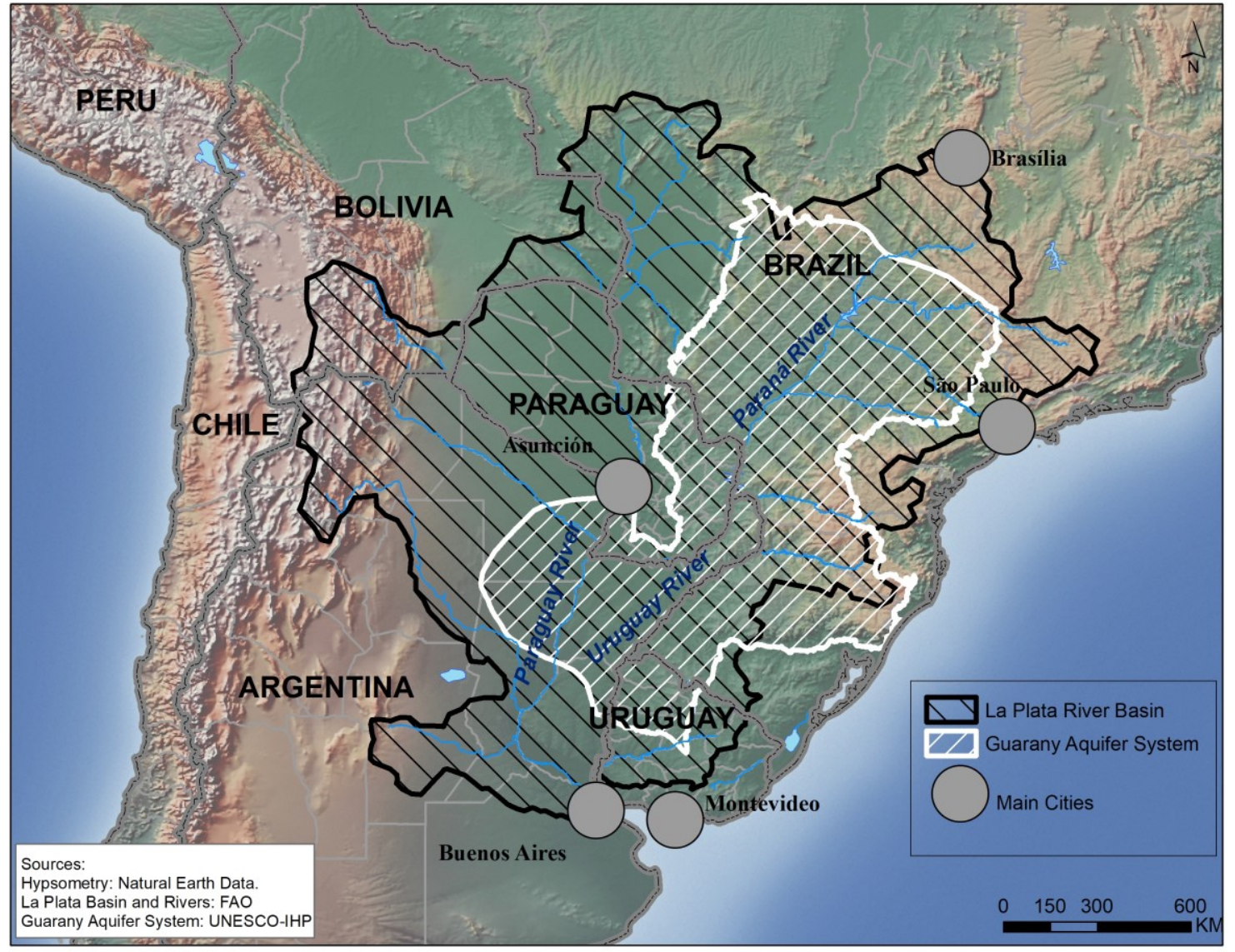

Figure 1: La Plata River Basin Guarani Aquifer System and its insertion within South America. Produced by the authors

\section{SCALING HYDROPOLITICS: INTERDISCIPLINARY APPROACHES TO A SCALAR ANALYSIS}

The concept of scale has come under intense scrutiny over the last two decades in geography.

Stemming from globalization and its relation to debates on environmental change, geographers argue that the concept of scale is of the utmost importance for human and environmental matters (Sayre, 2005; 2009). In water governance and hydropolitics, a growing number of scholars have addressed the issue of how the production of scales intersects with problems of the effectiveness of governance of international waters (Wolf, 1998; Uitto and Wolf, 2002; Sneddon and Fox, 2006; Reed and Bruyneel, 2010; Norman et al, 2015; Zinzani and Menga, 2017). 
Drawing on the arguments and debates about the ontology of scales and their politics, those analyses investigate how different scales - political, economic or ecological - are not solid natural containers, but socially contingent products (Swyngedouw, 1999; Brenner, 2001; Lebel et al, 2005; Brown and Purcell, 2005; Moss and Newig, 2010; Herod, 2011). Therefore, the next sub-sections provide a literature review of the debates over scale. These sections will provide the frame for the analysis of the South American case in section three.

\subsection{Scale as size in ecology and landscape ecology}

In ecology, particularly in landscape ecology, scale has been used to define the size of observable phenomena. For instance, a watershed is a landscape unit connected through the flow of water among its sources all along its mouth. Within this perspective, landscapes can be assessed through their mosaic composition, whether composed by corridors, patches, matrices or subunits within a watershed for planning, management and analytical purposes. Each one of these spatial forms has its own process and internal structures, therefore can be isolated and studied as a specific unit, and can be defined as a study scale (Forman, 1995; Wiens, 1989). Following this approach, scale is defined as the size of a discrete phenomenon over the terrestrial surface. Hence, Forman (1995) states that ecological studies could be made at several scales: a region, a landscape patch, a local ecosystem, or a river basin. This definition is strictly connected with the cartographical approach to scale, which corresponds to a relation between an area in the terrestrial surface represented through a map. Sayre $(2005 ; 2009)$ asserts that a corollary of this definition is an epistemological moment in any study, due to limited aspects that can be observed given a specific scalar grain (e.g. spatial and/or temporal resolution available within a given dataset) and extent (e.g. the size of the study area or the duration of the study). Therefore, any scale chosen to be studied has inherent constraints in terms of its reasoning. However, an attribute to the landscape or ecological system is to be an open system (e.g. that entails energy exchanges with other 
systems, through inputs and outputs). This characteristic is responsible for the diversity and the population of an ecosystem.

To deal with this scalar diversity and interaction, it is necessary to consider the theory of hierarchy. In this theory, each scale interacts with another within a vertical structure, then the scales are taken as levels participating in a hierarchical and nested organization. This conceptual structure enabled ecological analysis to focus on at least three levels in order to realize a multi scalar analysis: the analysis level, one upper, and one lower (McMaster and Sheppard, 2004). Sayre $(2005,2009)$ argues that the definition of scales as levels entails a scalar ontological moment, defined by the assumptions made to justify interactions among scales and their boundaries as an objective reality.

Gibson et al. (2000) shed light on some flaws of hierarchical theory. The factors they identify as misleading derive from the fact that the theory does not address the emergence of constitutive hierarchies (e.g. hierarchies that have their structures marked not only by the union of different scales). In constitutive hierarchies, raised in complex systems, the aggregation of smaller scales does not mean the union of their functions and processes, but creates emergent proprieties: "in complex, constitutive hierarchies, characteristics of larger units are not simple combinations of attributes of smaller units, but can show new, collective behaviours" (Gibson et. al. 2000: 221). Hence, within environmental geography the concerns about the distinctiveness of every scale becomes a prominent issue. Moreover, the distinctiveness and emergent properties are not just a feature of environmental processes, but are a concern with how political structures are built to cope with human-environmental systems. Problems of multi-level governance (Cash et. al., 2005; Lebel et. al., 2005) or of scale fitness (Moss and Newig, 2010) occur when organizations and institutions fail to take account of issues specific to their scale. 
Those issues of scalar interactions on environmental governance are more salient on the river basin because they are a hierarchical structure bound by the surface land that directs its flow into a common body; but, at the same time, is a social scale produced by material, discursive and conceptual actions, used for technical and political purposes (Cohen, 2015). The conflation and employment of these two scale definitions are derived by: the need to rationalize the hydrological features, what is feasible within a bounded and closed system; the manipulation of the resources, through the construction of infrastructure, such as dams and irrigation systems; and the aspiration to foster devolved and participatory water governance, stemming from the interdependencies among upper and lower water users (Molle and Worster, 2009, Cohen and Davidson, 2011; Cohen, 2015; Molle, 2015). An additional challenge stands when groundwater is considered on the governance of shared waters. Groundwater resources have a hidden aspect, which makes it difficult to set the scalar boundaries to define responsibilities and common policies. Although the amount of scientific data on the hydrological features of transboundary groundwater is increasing, knowledge about the uses, flows, contamination and connections between groundwater and surface water are still at exploratory pace (Jarvis, et al., 2005).

Finally, work that explores the challenges of implementing effective governance in multi-level environmental systems, river basins and groundwater systems is required to navigate different definitions of scale. Scale is generally defined as the spatial, temporal, quantitative or analytical dimension to study any phenomenon, while levels are defined as units of analysis that are located at different positions within a scale (Gibson et. al. 2000; Cash et. al. 2005; Moss and Newig, 2010). However, more recent attention to emergent properties in environmental systems as a constitutive hierarchy, has serious implications for the conceptualization of scale because the processes and structures of any scale upon analysis do not reflect only on their upper and lower scales, but propagate through the system. Human 
geography, in different ways and through different debates, has come to similar theoretical conclusions: that a scale is not only the aggregation of different levels or given containers, but instead each scale presents a distinct character built on particular ecological, social and political processes.

\subsection{Production of scales in human geography}

The concept of scale has been the subject of thirty years of discussion and critique in human geography. Some critiques have centred on the conceived idea of scales structured as nested hierarchies in social sciences - exemplified by the metaphors of the 'Russian dolls', the 'Chinese boxes` or '(scales as a) ladder' (Herod, 2011). Those conceptions about scale in human geography were questioned by geographers concerned with the political economic changes raised within processes of globalization. Questions such as the internationalization of production and the restructuring of the nation-state challenged the idea of fixed scalar containers. The theoretical achievements of these studies included a comprehension of the limits in assessing any particular scale with an ontological character, and the observation that there are no inherent conditions that make one particular scale more suitable for a social study (Sheppard and McMaster, 2004; Brown and Purcell, 2005). In further developments, new propositions were made that scales are socially constructed and built through social interactions. They are thus not seen as given by themselves, but instead are the consequence of agent actions in pursuit of a specific political agenda. Moreover, proponents of this perspective advocated that geographical investigations should consider the scales of social or ecological phenomena to scrutinize the strategies and motivations that gave rise to any scalar arrangement (Brown and Purcell, 2005; Swyngedouw, 2007).

Howitt $(1993,1998)$ argues that the uncritical acceptance of particular scales - i.e. urban, regional, national and global - tends to reduce complex processes to a priori labels. 
Therefore, the author follows physical geographers' conclusions that a specific scale is not just the merging of lower levels, but a discrete political and social construct. Further work proposes the adoption of the understanding of scales as relations (Howitt 1998, 2002). In this sense, scale can be assessed as a geographical totality, produced by the networking interactions among its attributes, with each totality having some autonomy. Depending on the perspective adopted to address the totality, some features can be emphasized, but they do not disappear at other scales, they just move into the background. For instance, the national scale is defined by features, such as territorial sovereignty, national market, cultural identity, regardless of the size of the country, which could be Russia or Singapore; and the national scale does not depend on features existing at another scale, such as subnational entities or supranational organizations. Hence, justifying what makes the national a relevant scale requires us to address the relations between those features (Howitt, 1998).

Brenner (2001) tries to bring a more realistic perspective over developments within the overall use of the term 'politics of scale' and the whole lexicon derived from this geographical concept. The main concern of this author is whether a socio-spatial phenomenon is indeed a problem of scale, or whether it might be better addressed through another concept, like territory, place or space. Furthermore, Brenner (ibid.) differentiates two main ways that empirical analyses about the politics of scale have been made. Firstly, he identifies a singular meaning of politics of scale, stated as "the production, reconfiguration or contestation of some aspect of socio-spatial organization within a relatively bounded geographical arena - usually labelled the local, the urban, the regional and so forth" (Brenner, 2001: 599). By contrast, secondly, he identified a more plural meaning, "politics of scale refers to the production, reconfiguration or contestation of particular differentiations, orderings and hierarchies among geographical scales" (Brenner, 2001: 600). 
The important point of differentiation between those two definitions is that for the plural politics of scale, the most important aspect of scalar analysis is the embeddedness and positionalities of spatial units interacting with each other. Hence, the geographical scale is "understood primarily as a modality of hierarchization and re-hierarchization through which processes of socio-spatial differentiation unfold both materially and discursively" (Brenner, 2001: 600). Consequently, the singular approach of scale, which prioritizes a self-enclosed spatial unit and its content, would be better addressed through the employment of an alternative geographical lexicon, such as place, territory or network. Nonetheless, the sociospatial phenomenon that would benefit from the deployment of scale and rescaling processes cannot be understood as a final and static structure. Those statements concur with the developments of physical geography when it asserts that properties of one scale may be invisible, or contradicted the properties observed at another scale, even within a same hierarchical organization, that there is no 'correct' scale for research and that the interactions across scales are of great interest (Wiens, 1989; Sayre, 2005).

Therefore, Brenner (2001) proposes some hypotheses to assess the processes of production and reproduction of spatial scales. These are some of the most relevant for this article:

- $\quad$ There are multiple forms and patterns of scalar structuration: any scalar structure must be evaluated, in terms of how, why and when socio-spatial processes are divided into a vertical hierarchy; which spatial units are relevant to that hierarchy; what are their roles within the structure; and what are their historical evolving relations with other spatial units. 
- Scales evolve relationally within tangled hierarchies and dispersed interscalar networks: Nevertheless, each geographical scale must be addressed in terms of its positionality within the context of other scales.

- There are multiple spatialities of scale. The areal terms in which scales are generally described are just one, among several, spatialities that scale can represent.

- Scalar hierarchies constitute mosaics and not pyramids. The geometries of scalar structures should not be understood as nested superposed levels, but as unevenly superimposed layers (Brenner, 2001: 605-607).

This short evaluation of the human geography literature about scale shows that, whilst the geographical scientific field is still far from a general conceptual definition and operational consensus, some approximation between different perspectives is possible, and perhaps desirable. Despite the criticisms of nested conceptualizations of scale, one of the most important benefits of scalar thought is to emphasize relations among levels in a hierarchical organization. On the one hand, instead of disregarding vertical connections, one of the most challenging efforts would be to identify the power relations that produce scalar structures. On the other hand, embracing Brenner's (op. cit.) arguments, scalar structuration does not mean, necessarily, a production of a bounded area within which power is exerted, spatially the metaphor of politics of scale can be territorialised in politics of position or politics of place (Lebel, 2005). In environmental governance those movements between scales and its different spatiality seem more intricate considering the intertwining of natural and jurisdictional scales of governance in socio-natural systems (e.g. Cohen and McCarthy, 2014). Most importantly, the production of scalar edifices, through techno-natural 
infrastructures, respond to political and ideological purposes, via discursive, material and physical interventions on river basins (Swyngedouw, 2007).

Together, these studies provide important insights into the emergent physical scales of hydropolitical interactions that become political produced scales. This topic can be best addressed under several perspectives in the case studies. Firstly, the LPRB and the GAS are along its biggest extension overlapping physical scales, defined by the movement and storage of water on and below ground. They are not physically independent, since groundwater interacts with surface water, and that is part of the complexity of the case, entailing struggles to build institutional governance for both scales. Second, the five states that share the LPRB and four that share GAS are socially produced scales that overlap the physical scales but exceed them. The coincidence of the state boundaries with the most important features of the physical scales (rivers and ridgelines) has important implications on the resource division. Third, the shifting dynamics of territorialisation, development and accumulation mobilized or facilitated by the five states over time, such as boundary demarcation, settlement, industrialization, urbanization and environmental conservation have set distinct land and water uses along the LPRB and GAS changing its interactions. Finally, the various ways that different sectors and strategies utilize water and reinforce the produced scales requires infrastructures, some of which are complementary and others contradictory. They require different amounts of financial investment and political agreements, which can entrain entities at other scales (e.g. international development banks). To summarize, these perspectives both produce and depend on scales in a relational, hierarchical, multiple, overlapping and superimposed sense.

3. TRANSNATIONAL HYDRO-GEOPOLITICS SCALES WITHIN LA PLATA RIVER BASIN AND THE GUARANI AQUIFER SYSTEM 
The LPRB, which encompasses parts of Brazil, Argentina, Paraguay, Uruguay and Bolivia, has a total area of 3.1 million $\mathrm{km}^{2}$, making it the second largest river basin in South America. The flow at the mouth of the river is the third largest in the continent, only surpassed by the Amazon and Orinoco (Castillo, 2011). What is commonly known as La Plata is the ensemble of three important river basins: the Parana River basin, with 1.5 million $\mathrm{km}^{2}$; the Paraguay River basin, with 1.09 million $\mathrm{km}^{2}$; and the Uruguay River basin, with $365,000 \mathrm{~km}^{2}$. These three river basins converge at the estuary of La Plata river, located on the border between Uruguay and Argentina, which drains an area of 130,000 km² (Elhance, 1999; Pochat, 2011; Queiroz, 2012).

Brazil occupies the greatest proportion of the river basin area $(46 \%)$, and the sources of the main rivers within the basin are in Brazilian territory. Argentina occupies $28 \%$ of the basin area, Paraguay 13\%, and the remaining $13 \%$ are shared between Uruguay and Bolivia (Elhance, 1999). Although Brazil has control of the largest area and the main water sources, it does not have control of the river mouth, which falls under joint Argentinian and Uruguayan jurisdiction. This spatial arrangement is the product of disputes over boundary demarcation and access to the ports at the river mouth (i.e. Buenos Aires and Montevideo) that date back to the Spanish and Portuguese colonial activities in South America leading up to independence.

Hence, as shown in Table 1, a consequence of this territorial setting is that Brazil interacts with any country within the basin, both bilaterally and multilaterally. What stands out in Table 1 is that the arrangement of the international boundaries within the river basin guaranteed Brazil access to the three main waterways (Paraguay, Paraná and Uruguay Rivers) and led to Brazil demarcating boundaries with every country in the basin. Furthermore, the rivers form, for the most part, the boundaries among these riparian states. Its access to all the main rivers and interactions with any other countries guaranteed Brazil an almost permanent 
geographical hegemony on its neighbours and on the rivers' flux. State boundaries often correspond with topographical features; however they are not a determinant aspect of hydropolitcal interactions. Rather, these boundaries have important implications for political agreements in order to exploit hydropower potential and build joint infrastructures.

Table 1: Brazil’s boundary extension with riparian states in the La Plata basin. Source: Second Commission on Boundary Demarcation (SCDL, acronym in Portuguese)

\begin{tabular}{|l|l|l|l|l|l|}
\hline $\begin{array}{l}\text { Boundary extension } \\
(\mathrm{Km})\end{array}$ & Total & $\begin{array}{l}\text { Rivers and } \\
\text { channels }\end{array}$ & Lakes & $\begin{array}{l}\text { Geometrical } \\
\text { lines }\end{array}$ & Watersheds \\
\hline Bolivia $^{\mathbf{1}}$ & $3,423.2$ & $2,609.3$ & $\begin{array}{l}63.0 \\
(1.8 \%)\end{array}$ & $\begin{array}{l}750.9 \\
(21.9 \%)\end{array}$ & \\
\hline Paraguay & $100 \%)$ & $(76.2 \%)$ & & & 436.9 \\
& $(100 \%)$ & 928.5 & & & $(32 \%)$ \\
\hline Argentina & $1,261.3$ & $1,236.2$ & & & 25.1 \\
& $(100 \%)$ & $(98 \%)$ & & & $(2 \%)$ \\
\hline Uruguay & $1,068.1$ & 608.4 & 140.1 & 57.6 & 262.0 \\
& $(100 \%)$ & $(56.9 \%)$ & $(13.1 \%)$ & $(5.4 \%)$ & $(24.5 \%)$ \\
\hline
\end{tabular}

In the 1990s, a new scale emerged for sharing water resources in South America, the Guarani Aquifer. It was given the official title Guarani Aquifer System (GAS) in 1996 following the epistemic community recognition of a unified set of relatively known groundwater reservoirs, which were discovered in the 1970s and 1980s. It covers a total area of approximately 1.1 million $\mathrm{km}^{2}$. SAG's area is within four countries, with its respective proportions: Brazil (71\%), Argentina (19\%), Paraguay (6\%) and Uruguay (4\%) (GEF, 2007).

It is argued that GAS is a new hydropolitical scale within and related with LPRB because this aquifer system is almost in its totality contained within the surface river basin. Nonetheless there are a number of important differences and similarities between underground and surface water. Among the differences are their flows, discharges and water distribution and the absence of Bolivia in its interstate arrangement. However, both GAS and LPRB are often interchangeable water supplies along the Southern Cone of South America, particularly where recharge and discharge of the aquifers take place. Therefore, the next

\footnotetext{
${ }^{1}$ Brazilian boundaries with Bolivia also include those within the Amazon River basin. These data do not differentiate between the two river basins.
} 
sections of the article scrutinize distinct moments of the production of LPRB and GAS scales, aiming to display its political, economic and ecologic intentions and outcomes.

\subsection{Production of the regional scale}

This section aims to analyse the role of water, either in rivers or aquifers, on the production of political scale at the regional level. This regional hydropolical scale aimed to regulate La Plata rivers' flows and build infrastructures, inserting LPRB and GAS at the hydrological mission (Molle et all, 2009). Since the independence of Latin American countries, Brazil and Argentina have been disputing the geopolitical hegemony of the South American Southern Cone. Rivers in the Cone have been fundamental to national and international trade. Due to their landlocked positions, Paraguay and Bolivia have a keen interest in the waterways, since this is their only sovereign route to the sea. Despite this, Brazil and Argentina have used their greater control over the transport networks to gain more influence over Paraguay, Uruguay and Bolivia. The regional waterways were employed as an asset used in bargaining with the smaller countries, and were an arena for dispute between the two regional powers.

Brazilian and Argentinian initiatives to improve navigation conditions were a frequent diplomatic issue in the region during the mid-twentieth century, but they also were the driver behind the development of the first institutional attempts to regulate water issues in the continent. During the 1960s, international organizations such as the Organization of American States (OAS), the Inter-American Development Bank (IDB) and the Economic Commission for Latin American and the Caribbean (ECLAC) supported the discussion of a treaty regarding the La Plata basin watercourses. The outcome of this process was the signing of the La Plata Basin Treaty in 1969, which established the benchmarks for the use of water resources and the development of regional infrastructure projects. This treaty is seen as one of the first steps to create a cooperative hydropolitical scenario (Elhance, 1999; Castillo, 2011; Biswas, 2011; Pochat, 2011). 
The accomplishment of the La Plata river basin treaty was to build the institutional framework to regulate hydropolitical relations between the countries (Pochat, 2011). The influence of the treaty over the hydropolitical initiatives is channelled through two institutions created to articulate and develop policies regarding the development of the basin: the Inter-governmental Co-ordination Committee (CIC Plata) and the Financial Fund for the Plata Basin (FONPLATA). The CIC, created even before the signing of the La Plata treaty, is responsible for the execution of projects on water issues. The FONPLATA, created in 1976, is responsible for financing development projects in the La Plata countries. It receives funds from the signatory countries and also from other international institutions. Until 2011, FONPLATA approved development projects worth US\$ 1.04 billion.

Although the LPRB and the GAS waters are physically connected, they are seen to be distinct from a socio-political lens, hence they have been considered and governed independently. In the case of the GAS, the epistemic community - meaning researchers and academics from the four countries - played a central role in advancing knowledge on the GAS (Villar, 2016; Walter, 2015). In fact, while until the 1990s it was believed that the aquifer was not transboundary, but as several independent aquifers, the epistemic community conducted research concluding that the Guarani groundwater resources are part of a unified aquifer system (Walter, 2015; Villar, 2016). This finding, as highlighted by Water (2015: 23), had an important impact on the production of a regional scale. The Guarani groundwater resources were to be seen as a regional shared unified system, and this meant that local challenges were to be situated within the regional context. This also impacted the governance of the GAS, which had to be considered regionally by the four countries - Argentina, Brazil, Paraguay, and Uruguay - rather than nationally. The interconnection of the groundwater resources also meant that overexploitation and pollution in one country would result in an increase of its quality also in the other three countries. This pushed for regional initiatives 
focusing on monitoring the quality of the shared groundwater resources, especially in light of over exploitation in Brazil for industries, Paraguay for irrigation, and Argentina and Uruguay for thermal tourism.

The call to boost regional cooperation was received by regional organisations, including the MERCOSUR and PARLASUR, which supported regional cooperation (Villar, 2016; Villar and Ribeiro, 2011; Gómez-Mera, 2013). A regional project, supported by the GEF, the OAS, and the World Bank, allowed the four countries to start the Environmental Protection and Sustainable Development project of the GAS Project in 2000 (Patole, 2015). Its aim was to produce a study on the GAS and provide recommendations for the long-term management of the GAS (World Bank, 2002). Consequently, the production of the regional hydropolitical scale, initiated by the epistemic community, was reinforced by regional and international organisations. This scale was successfully promoted by the GAS Project, which operated from 2003 till 2009.

\subsection{Role of treaties in shaping the LPRB and GAS scales}

Agreements and treaties were one of the main political and institutional tools to build a regional hydropolitical scale in South America. Concerning the GAS, one of the aims of the Guarani Project, developed during the 2000s, was to agree a framework regarding institutional, technical and legal settings for the GAS (Villar, 2016). However, when the project ended in 2009, this goal had not been achieved. Nevertheless, the project was successful in building dialogue among the four countries and initiating transboundary cooperation. In fact, this dialogue and cooperation enabled the four countries to sign the Guarani Aquifer Agreement in 2010. However, this agreement is not yet in force as it has been ratified only by Argentina and Uruguay. This agreement produces a regional hydropolitical scale for the GAS; it aims at reducing asymmetric information on the GAS 
(Cassuto and Sampaio, 2013: 31), establishes a regional commission (including its functions and powers), and provides it with the responsibility to set an additional protocol to the agreement to define mechanisms for dispute resolution (Villar and Ribeiro, 2011). The agreement would reinforce the GAS as a regional hydropolitical scale, it would allow a better operationalization of the commission and its structures and powers, as well as implementation of the agreement, making transboundary groundwater cooperation effective at a regional scale.

Brazil plays an important role in shaping the production of the GAS scale by determining whether the agreement will be approved or not. From a technical perspective, the agreement has been approved; what is missing is the political approval from Brazil and Paraguay through their ratification of the agreement. Brazil plays a central role also because it is the most powerful of the four countries and the largest user of GAS resources. The Brazilian state of São Paulo, the most populous state in Brazil, heavily relies on the GAS for municipal and domestic water supply (Dettoni, 2013). Given its powerful role in the region and high stake in the GAS, Brazil can determine the future of the GAS agreement by delaying or opposing its implementation (Hussein, 2018).

Nevertheless, as noted by Villar (2016), the production of a regional hydropolitical scale for the GAS was significantly advanced by the GAS project and agreement. Although the agreement has not been ratified, it has created the Regional Centre for Groundwater Management for Latin American and the Caribbean (CeReGAS) in Montevideo, Uruguay, in partnership with UNESCO-IHP, which aims to promote cooperation over transboundary groundwater resources in the region. Hence, this regional centre has contributed to the creation and reinforcement of the GAS in its regional dimension. 
However, in the LRPB case, the ratification of the LPRB treaty did not resolve the tensions among the La Plata countries. Ferres (2004) argues that the success of the treaty was the result of an Argentinian diplomatic victory, which convinced the downstream countries to cooperate on water resources for development purposes in order to antagonise Brazil. At first, the Brazilian military government considered the possibility of allying itself with its downstream neighbours through a treaty to reinforce its upstream position and economic power. However, Brazil imposed the inclusion of a clause containing the obligation to inform other riparian countries of any work intended on the rivers within the La Plata basin. Brazil agreed to sign the treaty to prevent loosening its hegemonic influence over the countries in the region to Argentina. The previous clause about work in the river was inserted within the treaty signed to resolve disputes about dams on the Parana River, between Brazil, Argentina and Paraguay.

The La Plata treaty ratification triggered the first in a series of the disputes between Brazil and Argentina. The strengthening of the national interests came with the growing demand for energy, due to rising urbanization and industrialization of the regional inland. The building of roads reduced the use of La Plata rivers for transport. Therefore, the river basin scale framed by the treaty began to engage disputes and negotiations about the damming of its waters.

Also, Brazil attempted to extend its regional hydropolitical influence through a series of bilateral and trilateral treaties on the LPRB, advancing its hydropolitical influence and expanding its infrastructural projects. The construction of large hydropower projects started to characterize disputes over the use of La Plata water resources in the mid-1970s. Since the main urban and industrial centres in South America are within the basin, its potential for energy generation came to be seen as a basis for national development plans. The initiative of riparian national governments to develop hydroelectric power plants and navigation was 
facilitated by financial resources from international agencies and banks, such as the World Bank and Inter-American Development Bank (IDB). On the one hand, these projects exacerbated conflicts between countries due to interdependences related to the positions of these projects. On the other hand, the resolution process was supported by the spaces of dialogue and cooperation on hydropolitical issues established by the La Plata treaty.

The most complex dispute among the countries was over the hydropower plants of Itaipu and Yacyretá, between Brazil, Argentina and Paraguay. The hydroeletrical potential of La Plata basin is one of the greatest in the world, because of its topographical gradient and the abrupt rift between the Central Brazilian plateau and the Chaco depression (Figure 2). Currently, around $60 \%$ of the basin potential is already exploited through more than 100 hydropower plants either in operation or under construction. This represents approximately $49 \%$ of Brazil's total energy output (Pochat 211: 499). 


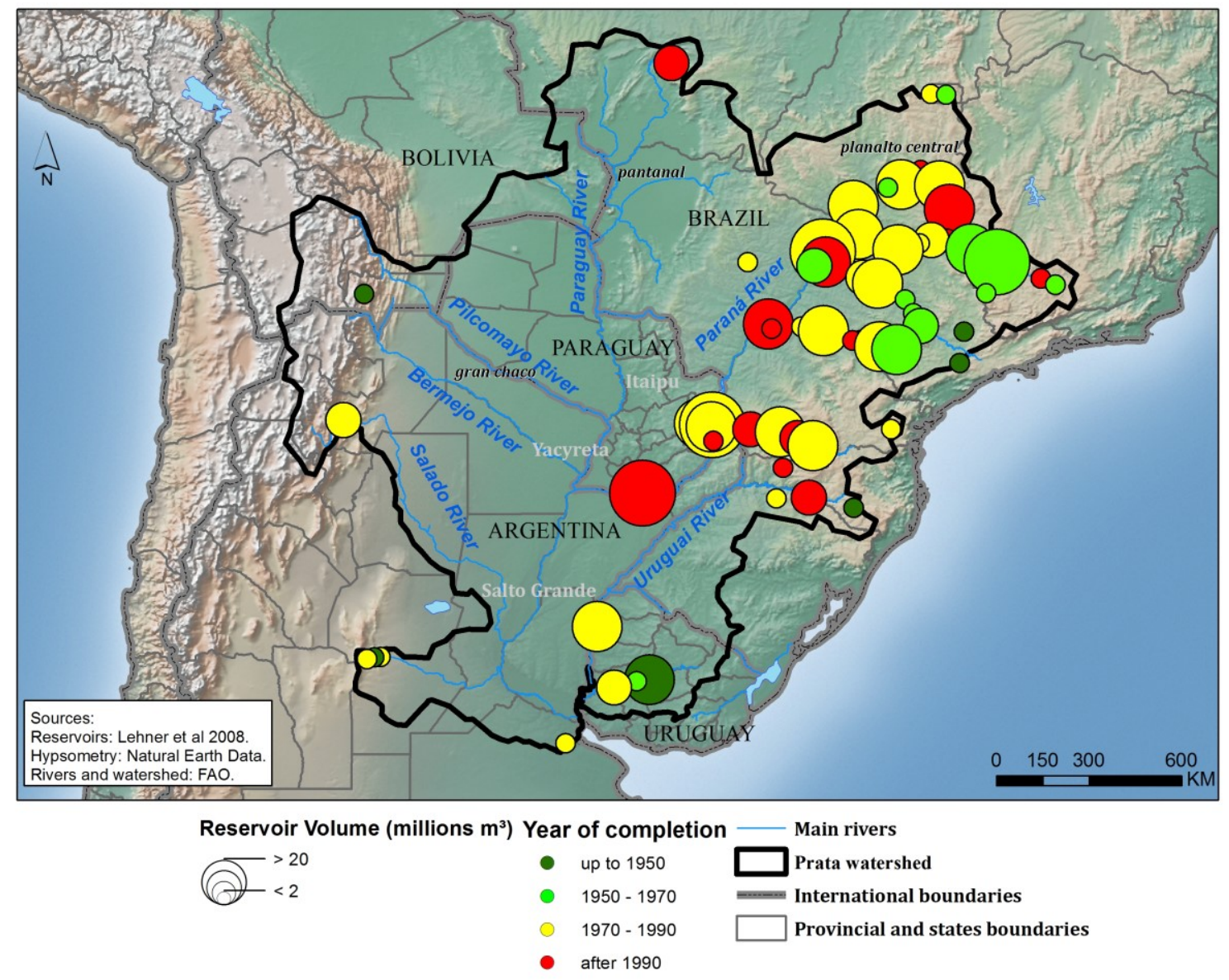

Figure 2: La Plata River Basin: Main reservoirs, by volume and year of completion. Produced by authors.

According to Figure 2, the distribution of dams and reservoirs within the LPRB, follow the increasing urbanisation and economic growth in the countries. The bulk of hydropower construction happened in the mid-twentieth century, beginning on the main tributaries of the Paraná River, like the Tietê River near its major south-eastern estates (São Paulo, Rio de Janeiro and Minas Gerais); and then expanding to the Paraná River itself, following the urban and agricultural frontier (Elhance 1999). It is noteworthy that three of the biggest dams were bilateral projects: Salto Grande (Uruguay and Argentina), Itaipu (Brazil and Paraguay) and Yaciretá (Argentina and Paraguay).

The negotiations over the construction of large dams had begun in the 1960s, when the first inventories of hydropower potential along the Paraná River were made, along the BrazilParaguay border. The proposal was to develop a joint energy resources exploitation project 
on the river. However, following the coup d'état that removed João Goulart from power, in 1964, the negotiations were halted and the Paraguayan government started to request a review of its boundaries with Brazil. The Paraguayan allegation was that in the Sete Queda region the boundary treaty was not clear about the position of the boundary, which might allow Paraguay to gain some territory from Brazil. In 1965, both Brazilian and Paraguayan armies occupied the river bank upstream of the first of the seven falls, near the towns of Mundo Novo, in the Brazilian state of Mato Grosso do Sul, and Guaíra, in the Brazilian state of Paraná. The conflict was settled the following year, with the signing of the Itaipu agreement, where it was also agreed that future joint energy projects on the Paraná River, between the mouth of the Iguaçu River (a southern tributary of Paraná River) up to the Sete Quedas, ought to share the energy yield equally between the two riparian countries. The agreement was enforced in 1973, with the Itaipu treaty, at the same time creating a binational company to build and manage the hydropower plant. Finally, the boundary question within the reservoir area was resolved by the flooding of the contentious area and the creation of an ecological reserve on the left bank of the river (which also represents the international boundary) (Oliveira, 2012).

In the same year, Paraguay signed a similar treaty with Argentina to build another dam, the Yaciretá dam, also in the Paraná River, but downstream of Itaipu. The proximity between the agreements of those two diplomatic treaties, in terms of their content, time of signing and geographical position, was not a coincidence, but was the result of the efforts of Brazil and Argentina to exert political and economic influence over Paraguay. Paraguay also used its geographical position within the river basin to negotiate investments and play a role in the regional politics. Today, Itaipu and Yaciretá remain the largest hydropower plants within LPRB and have turned Paraguay into a large hydropower exporter. The two treaties are very similar, establishing binational companies to manage the dams and sell the energy 
production, and most of the expenses being borne by Brazil and Argentina, with Paraguay having to sell the energy surpluses below market prices, therefore burdening Paraguay with a large foreign debt (Elhance 1999; Pochat 2011).

Negotiations over the binational treaties for Itaipu and Yaciretá happened at the same time as the terms of the multilateral La Plata basin treaty were being defined. On the one hand, Paraguayan bilateral treaties put Brazil and Argentina on opposite sides, since the position of Itaipu along the Paraná River gave Brazil advantage to dam its waters. On the other hand, the La Plata basin treaty was the first attempt to create a diplomatic mechanism to negotiate the technical parameters to exploit the river. However, as argued by Candeas (2010), the La Plata treaty does not achieve the goal to attenuate the tensions among signatory countries, because it was firstly focused to improve, politically and technically, the navigational conditions, but does not deal specifically with hydropower issues. A strong Argentinian mistrust over Brazilian intentions to dam the Paraná River continued to predominate, jeopardizing their downstream projects.

Following the 1976 coup d'état in Argentina, the governments of the largest countries in the region looked for an agreement regarding the technical hydropower questions and broader concerns about regional integration within South America's Southern Cone. At that moment, Itaipu dam was being built and Argentina joined Paraguay to launch another hydropower plant on the Paraná River, the Corpus dam. Because of the proximity between these two dams, their performance would be intertwined (Figure 3). If the reservoir of the Corpus dam was too big, it could decrease Itaipu`s gradient, therefore decreasing its potential; conversely, if the Itaipu dam were bigger, Corpus would not have enough water to run its turbines. At the beginning of construction, Brazil was not keen to limit its capacity to produce energy at Itaipu but Argentina tried to establish an agreement with Brazil through diplomatic means and through media campaigns about the negative impacts of Itaipu on the 
Argentinian economy, alleging that Brazilian construction in Itaipu was an attempt to exert regional dominance (Ferres, 2004). In 1979 Brazil, Argentina and Paraguay signed the tripartite Itaipu-Corpus treaty, defining the level of water that each country could keep in its reservoir without affecting downstream neighbours, thus resolving this conflict (Candeas, 2010). Some authors argue that the Brazilian military government only accepted to commit to the hydrological limits in Itaipu, therefore ensuring Corpus` feasibility, when they changed their foreign policy stance. In the 1980s Brazil started to strengthen its regional ties, seeking a stronger regional integration and to become more independent of the influence of the United States, a policy that culminated in the formation of the Southern Common Market (MERCOSUR) in 1991. Brazil subsequently enjoyed a period of cooperation with its South American neighbours on economics, politics and environmental issues (Ferres, 2004; Queiroz, 2012). Since the Corpus dam project was not pursued by Argentina and Paraguay, because of other economic and political reasons, the tripartite treaty is the institutional mechanism that dictates the amount of water that can be dammed by each country and that guarantee the use of water for different uses in the Paraná River, including navigation (Ferres, 2004). 


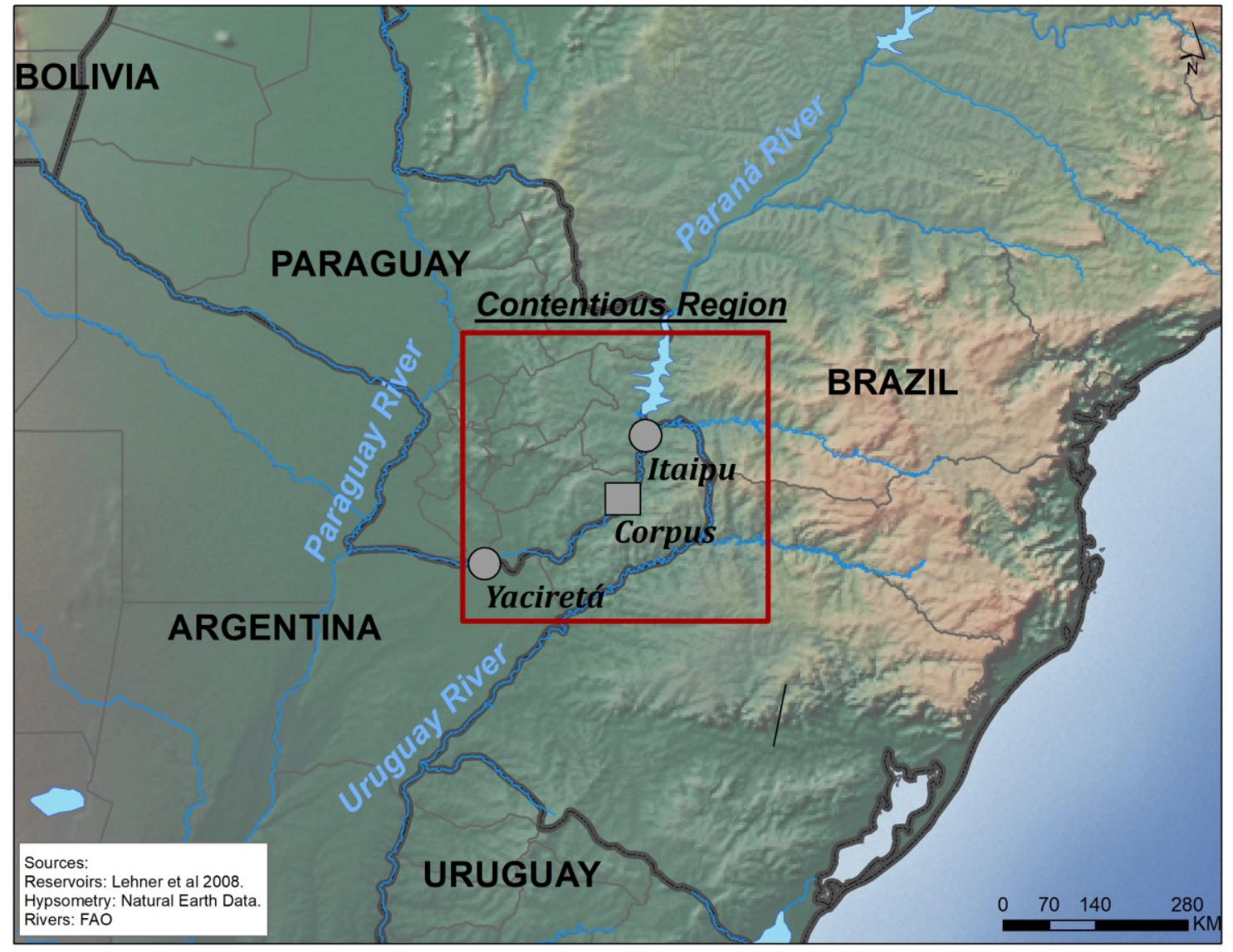

Figure 3: "The disagreement map". Showing the sites of the hydropower plants of Itaipu, Corpus and Yaciretá, along the Paraná River, and the contentious region. Produced by authors.

\subsection{The emergence of environmental concerns and formal and informal}

\section{cooperation on different scales}

The $21^{\text {st }}$ century came with a changing approach for water governance at LPRB and GAS.

The hydraulic mission has made La Plata the main source for hydropower in South America and its irrigated land yields grain for countries across the world. Additionally, the aquifer system is under increasing stress, being depleted to provide water for municipal and industrial users and then being threatened with pollution and contamination.

Regarding the issue of surface water, river basin hydropolitics has been seen as a broad consensus; however, raising awareness about climate change and its effects on fluvial dynamics has been addressed through the river basin scale with new forms of collaboration 
among riparian countries (Villar, Ribeiro and Sant'Anna, 2018). Table 2 shows the trend of agreements and treaties being signed among LPRB countries regarding its tributaries after issuing the 1969 La Plata Treaty. Firstly, many actions were undertaken on development subjects, such as the hydropower production. However, starting at the end of the 1980s the conservation of aquatic environments and sustainable development began to be addressed among the LPRB riparian countries.

Table 2: Binational and Tripartite agreements and treaties among LPRB countries, concerning its tributaries, signed after the 1969 La Plata Treaty, and its main subject.

\begin{tabular}{|c|c|c|c|}
\hline Agreement or treaty & $\begin{array}{l}\text { Signatory } \\
\text { Countries }\end{array}$ & $\begin{array}{c}\text { Year of } \\
\text { signature }\end{array}$ & Main subject \\
\hline $\begin{array}{l}\text { Agreement for the study and exploitation of } \\
\text { natural resources at Paraná River }\end{array}$ & $\begin{array}{c}\text { Argentina } \\
\text { and Paraguay }\end{array}$ & 1971 & $\begin{array}{c}\text { Water resources } \\
\text { exploitation }\end{array}$ \\
\hline Treaty of Itaipu & $\begin{array}{l}\text { Brazil and } \\
\text { Paraguay }\end{array}$ & 1973 & $\begin{array}{l}\text { Hydropower } \\
\text { production }\end{array}$ \\
\hline Treaty of Yaciretá & $\begin{array}{c}\text { Argentina } \\
\text { and Paraguay }\end{array}$ & 1973 & $\begin{array}{l}\text { Hydropower } \\
\text { production }\end{array}$ \\
\hline Treaty of La Plata River and its Maritime Front & $\begin{array}{l}\text { Argentina } \\
\text { and Uruguay }\end{array}$ & 1973 & $\begin{array}{c}\text { Water resources } \\
\text { exploitation }\end{array}$ \\
\hline Agreement of Uruguay River & $\begin{array}{l}\text { Argentina } \\
\text { and Uruguay }\end{array}$ & 1975 & $\begin{array}{c}\text { Water resources } \\
\text { exploitation }\end{array}$ \\
\hline $\begin{array}{l}\text { Treaty of cooperation, exploitation of natural } \\
\text { resources and development of the Mirim Lake } \\
\text { basin }\end{array}$ & $\begin{array}{l}\text { Brazil and } \\
\text { Uruguay }\end{array}$ & 1977 & $\begin{array}{c}\text { Water resources } \\
\text { exploitation }\end{array}$ \\
\hline Tripartite agreement of Itaipu - Corpus & $\begin{array}{l}\text { Argentina, } \\
\text { Brazil and } \\
\text { Paraguay }\end{array}$ & 1979 & $\begin{array}{l}\text { Hydropower } \\
\text { production }\end{array}$ \\
\hline $\begin{array}{c}\text { Treaty for the exploitation of the shared Waters } \\
\text { at the boundary of Uruguay river and its } \\
\text { tributary Pepiri-Guazu river. }\end{array}$ & $\begin{array}{l}\text { Brazil and } \\
\text { Argentina }\end{array}$ & 1980 & $\begin{array}{l}\text { Water resources } \\
\text { exploitation }\end{array}$ \\
\hline $\begin{array}{l}\text { Agreement of cooperation between the Republic } \\
\text { of Argentina and Oriental Republic of Uruguay to } \\
\text { prevent and fight against contamination } \\
\text { incidents in aquatic environments. }\end{array}$ & $\begin{array}{l}\text { Argentina } \\
\text { and Uruguay }\end{array}$ & 1987 & $\begin{array}{l}\text { Preservation and } \\
\text { conservation of } \\
\text { aquatic } \\
\text { environments }\end{array}$ \\
\hline $\begin{array}{c}\text { Agreement for the river transport between the } \\
\text { Oriental Republic of Uruguay and the Republic of } \\
\text { Argentina }\end{array}$ & $\begin{array}{l}\text { Argentina } \\
\text { and Uruguay }\end{array}$ & 1991 & Transport \\
\hline
\end{tabular}




\begin{tabular}{|c|c|c|c|}
\hline $\begin{array}{l}\text { Agreement of cooperation for the exploitation } \\
\text { and development of natural resources in Quaraí } \\
\text { river basin }\end{array}$ & $\begin{array}{l}\text { Brazil and } \\
\text { Uruguay }\end{array}$ & 1991 & $\begin{array}{l}\text { Water resources } \\
\text { exploitation }\end{array}$ \\
\hline $\begin{array}{l}\text { Agreement for the river transport through the } \\
\text { Paraguay-Paraná hydroway }\end{array}$ & $\begin{array}{c}\text { Argentina, } \\
\text { Bolivia, } \\
\text { Brazil, } \\
\text { Paraguay and } \\
\text { Uruguay }\end{array}$ & 1992 & Transport \\
\hline Agreement over the lower Pilcomayo river & $\begin{array}{c}\text { Argentina } \\
\text { and Paraguay }\end{array}$ & 1993 & $\begin{array}{l}\text { Preservation and } \\
\text { conservation of } \\
\text { aquatic } \\
\text { environments }\end{array}$ \\
\hline $\begin{array}{l}\text { Agreement between the government of the } \\
\text { Republic of Paraguay and the government of the } \\
\text { Republic of Brazil to preserve its aquatic fauna } \\
\text { within its boundary river courses }\end{array}$ & $\begin{array}{l}\text { Brazil and } \\
\text { Paraguay }\end{array}$ & 1994 & $\begin{array}{l}\text { Preservation and } \\
\text { conservation of } \\
\text { aquatic } \\
\text { environments } \\
\end{array}$ \\
\hline $\begin{array}{l}\text { Tripartite agreement constituent of the } \\
\text { Pilcomayo river commission }\end{array}$ & $\begin{array}{l}\text { Argentina, } \\
\text { Bolivia and } \\
\text { Paraguay }\end{array}$ & 1995 & $\begin{array}{l}\text { Water resources } \\
\text { exploitation } \\
\text { Preservation and } \\
\text { conservation of } \\
\text { aquatic } \\
\text { environments }\end{array}$ \\
\hline $\begin{array}{c}\text { Agreement for the multiple natural resources } \\
\text { development at Bermejo river high basin and } \\
\text { Grand Tarija river }\end{array}$ & $\begin{array}{l}\text { Argentina } \\
\text { and Bolivia }\end{array}$ & 1995 & $\begin{array}{l}\text { Water resources } \\
\text { exploitation } \\
\text { Preservation and } \\
\text { conservation of } \\
\text { aquatic } \\
\text { environments }\end{array}$ \\
\hline $\begin{array}{l}\text { Agreement of cooperation for the sustainable } \\
\text { development and the integrated management of } \\
\text { Apa river basin }\end{array}$ & $\begin{array}{l}\text { Brazil and } \\
\text { Paraguay }\end{array}$ & 2006 & $\begin{array}{l}\text { Water resources } \\
\text { exploitation } \\
\text { Preservation and } \\
\text { conservation of } \\
\text { aquatic } \\
\text { environments }\end{array}$ \\
\hline Guarani Aquifer Agreement & $\begin{array}{l}\text { Argentina, } \\
\text { Brazil, } \\
\text { Paraguay and } \\
\text { Uruguay }\end{array}$ & 2010 & $\begin{array}{l}\text { Water resources } \\
\text { exploitation }\end{array}$ \\
\hline
\end{tabular}

Sources: POCHAT, 2011; CTGRHT, 2014 and FAOLEX, 2017.

From 2001 onwards, environmental concerns started to integrate CIC Plata policies through the elaboration of the "sustainable management of water resources in La Plata basin program, regarding the effects arising from the climate change and variability" (CIC, 2011a). This regional scope research, commissioned by the Global Environment Facility (GEF), aimed at 
the elaboration of a social and environmental assessment for La Plata, working towards the construction of local programs to mitigate environment degradation and preservation. Thereby, the "Framework Program", as it came to be known, intended to integrate and articulate the projects already in progress within the river basin, as well as propose new ones. It is worth noting that ideas and inspiration for this program came from the World Water Fora, especially the forum in The Hague in 2000 (Tucci, 2004; CIC, 2011b). Although the La Plata treaty is open to adaptive policies depending on local issues, one of the treaty`s main goals was to implement a common vision of water resources within the La Plata river basin. In this sense, the Framework Program was a turning point in the trajectory of the river basin initiatives regarding the focus on environmental conservation and concerns over the regional effects of climate change. Similarly, also on the GAS, environmental, climate change and water quality concerns pushed the governments and in particular the local communities and councils to strengthen cooperation at different scales. Guided by these concerns, while the GAS Project was a regional project, it promoted a local scale of the GAS, which co-existed with the regional dimension of the aquifer. The GAS Project envisioned four pilot projects of bilateral commissions at the local scale. Their aim was monitoring, data exchange, and the promotion of joint projects. One of the few examples worldwide of local management of transboundary groundwater governance is the bi-national Argentinian-Uruguayan Salto/Concordia Commission on the GAS; there, two cities through an ad-hoc institution manage the GAS governance. The commission has been successful in monitoring and data collection and exchange, and is still functional although its fixed term expired in 2009. It could be said that the GAS project pushed forward this regional cooperation with a local component, especially regarding the technical studies and data exchange, building partnerships in the four pilot projects of bilateral commissions at the local scale (Walter, 2010). 
Silva (2017) examines one example of local environmental initiatives at the Brazilian Uruguayan border, held at the Quaraí river basin. This is an interesting site of political interactions among many social actors because it is a transboundary river basin and an outcrop and recharge zone of the SAG. Irrigated rice crops use roughly $97 \%$ of the river basin runoff, which is mainly used during the seeding period, which happens during the dry season (i.e. December to February). Therefore, during these months, water used at the rice yields surpasses the water used for municipal users, causing disputes over water between rural and urban users, and between rice farmers situated at high or lower parts of the river basin (Mello, 2016²; Wagner, $2016^{3}$ ).

During the 2000s the lack of water at the main Brazilian and Uruguayan border cities escalated to the extent that the Uruguayan government made formal complaints to Brazil accusing Brazilian farmers as being responsible for the dry taps. Foreign affairs ministries began to enforce the 1991 "Agreement of cooperation for the exploitation and development of natural resources in Quaraí river basin" (Table 2), by creating the binational committee. Meanwhile, municipal governments started to build wells in order to extract water from the Guarani Aquifer (Mello, 2016; Wagner, 2016). The urban droughts were resolved, however, profligate farmers were not made accountable and demand-side management measures were not addressed.

\footnotetext{
${ }^{2}$ Interview held in Quaraí, Rio Grande do Sul, Brazil, July 2016.

${ }^{3}$ Interview held in Santana do Livramento, Rio Grande do Sul, Brazil, July 2016.
} 


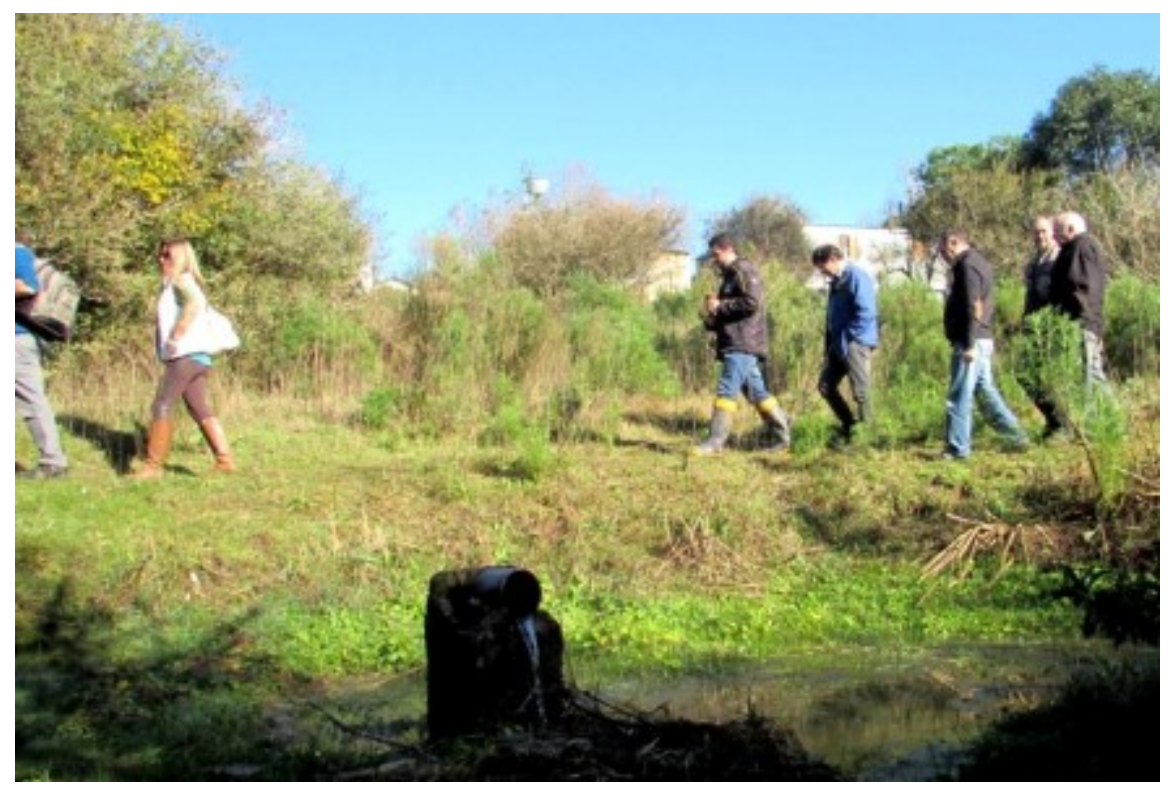

Figure 4: Outcrop of the SAG in Santana do Livramento, Brazil. In the background, irregular settlements are shown and the water spring is not under shelter. Source: authors, 2016.

Finally, at the end of the 2000s, the growth of rice yields either in Brazil and Uruguay led to an increase of water damming during the seeding season. Although Brazilian and Uruguayan farmers have a number of social and business ties, the dams led to disputes (Meirelles, 2016) ${ }^{4}$. In 2007, since the Brazilian National Water Agency (ANA) has not been able to hold talks in order to resolve the disagreements, sub-national and private actors started to articulate the transboundary hydropolitics at the border region (Mello, 2016; Wagner, 2016). Moreover, in 2009, Uruguay approved a new water law which gave more power to local and private stakeholders to address local and regional issues through the construction of river basin committees (Uruguay, 2009). Hence, ANA in partnership with rice farmers took hold of the local hydropolitical spheres, enacting norms to cope with drought periods. The most know norm set by the agriculture actors parlance is the "ruler rule", which defines the decreasing of water pumping at the Quaraí river bed depending on the river's level mark in a rule located below the international bridge between the cities of Quaraí (Brazil) and Artigas

\footnotetext{
${ }^{4}$ Interview held in Santana do Livramento, Rio de Grande do Sul, Brazil, July 2016.
} 
(Uruguay). In 2009, this norm was stated by ANA, and endorsed in Brazil, and in Uruguay (Silva, 2017).

This new framework has produced devolved water governance on the Brazil - Uruguay border. Driven by the rice farmers' interests, this new transboundary scale intertwined local actors with subnational and federal actors. It also connected the uses of surface water and groundwater, then LPRB and GAS. The use of GAS waters to supply Quaraí river basin's cities deferred the confrontation with the surface water issues and the improvement of the sanitation conditions, since agricultural and livestock are the most significant polluters within the basin (Quaraí, 2014). Regarding the groundwater, since outcrop and replenishment aquifer areas are the most vulnerable to anthropogenic contamination the exploitation of this reservoir must be handled in a careful manner (Amore, 2011). However, this is not the case in areas such as those illustrated by Figure 4, where households are without protection from the wells.

\section{DISCUSSION}

This article highlighted the role of production of scale and the different ways and techniques deployed in South American regional hydropolitics. The production of scale is a relevant concept because it sheds light on the spatial framings embraced by social actors in order to share and use water resources. Different scales were forged in order to pursue different interests. For instance, the use of the La Plata river to produce hydroelectric power, to transport goods and to support economic development were the main themes characterising regional hydropolitics during the twentieth century. The projects, agreements and treaties resulting from those hydropolitical interactions were the outcome of national political arrangements, with the support of supranational organizations, which determined and constructed different scales. Treaties such as the 1969 La Plata treaty and the 1979 tripartite 
agreement of Itaipu-Corpus set the scene for concerted political interactions taking the river basin as a single spatial frame to address joint issues along the development of hydraulic missions in South America. Thus, the construction of large dams resulted in positional disputes addressed by the construction of binational and tripartite scales, such as the Corpus agreement.

Another instance of constructing scale in hydropolitics in the region relates to environmental concerns about transboundary water resources, either as a specific issue of national governments and NGOs or as an outcome of development projects. CIC Plata among other agencies at the Southern Cone started to assess the environmental concerns through projects like the Framework Program. Meanwhile, increased exploitation of groundwater inserted GAS resources to the hydropolitical setting in South America. Its acknowledgement stems from the academic concern with this still unknown water resource and possible contamination caused by its undue exploitation. Given the absence of specific normative rules for transboundary groundwater, surface transboundary river basins were taken as inspiration to carve out one of the first international initiatives to govern and manage shared transboundary waters, the 2010 Guarani Aquifer Agreement. Therefore, specific agreements concerning environmental governance call attention to a current trend of regional hydropolitics. This result may be explained by the fact that increasing worries about climate change, the harmful effects of economic uses of water and their changes on international water regimes are influencing South American water sector actors, which are seeking to introduce environment related topics into projects and joint actions along transboundary water systems.

Additionally, this article argues that scalar approach in ecology is also of great interest to hydropolitical studies since the surface river basin is physically entangled with groundwater, thus their governance actions should be thought in an intertwined manner. The LPRB and the 
GAS are physically and materially overlapping and connected through the movements of water between the surface and below ground storage. On one hand, ecological scalar theories highlight how a water system, either La Plata or Guarani Aquifer, has a spatial extension which embrace social actors engaged in governing water uses and its control. Ecology also underlines the connections among differing levels of organizations; each one has an enlarged complexity derived from the arrangement of actors. On the other hand, human geography thought introduced the production of scale onto geographical debates arguing that power relations are determinant to the spatial framing of environmental governance. In LPRB and GAS, national states were the main drivers of the first attempts to set joint governance of shared water. National interest was driven by the use of water as a natural resource to produce hydropower and foster national development. Nevertheless, in the twentieth century, economic development goals inserted new actors into regional hydropolitics, for instance international development banks and multilateral organizations, like BIRD and CIC Plata. More recently, new layers have been added to the hydropolitical scales, such as international epistemic communities and NGOs. Those actors are addressing environmental issues and are producing more decentralized initiatives on local users of water and coping with the impact of development projects on water reservoirs. Despite the new layers, policies and institutions launched during the hydropower rush are still informing the transboundary interactions, because they have built a structure for conflict resolution and joint governance on hydropolitics. These results support the argument that transboundary water uses both produce and depend on the concept of scales in Neil Brenner's (2001) sense - i.e. relational, hierarchical and overlapping.

Another important finding regarding the production of scale in South America's hydropolitics is the Brazilian hegemonic role in the region. Brazilian hegemony was built through negotiations with its neighbours, mainly Argentina. Given its spatial extension and 
economic uses of water resources Brazil is the leading state along the process of scalar construction. Its interests are represented in the devising of treaties and agreements in the region. For instance, Brazilian eagerness to develop hydropower infrastructure was the driver of the inventories, studies, negotiations and exploitation of Paraná River's hydropower potential. Nowadays, this river is the main source of hydropower for the Brazilian and Argentinian economic cores. The attempts to foster development were concerted with the La Plata's river basin treaty and tripartite Itaipu-Corpus agreement. Paraguay bargained those deals under the leverage of its advantageous position within the river basin, which yielded access to all the main tributaries of La Plata. Bolivia and Uruguay played a minor role in these discussions, since they share a small area of the river basin. However, Bolivia has an explicit interest on waterway transport in LPRB because it is the only sovereign exit to the Atlantic Ocean of this landlocked country. On GAS, Brazil's exercise of hegemony is complex, and it has relied on different types of power: bargaining power, through adding clauses and shaping negotiations in Brazil's interest as well as through delaying the ratification process; and hard power, through its economic, geopolitical, and military importance in the region; and through its geographical position, as most of the GAS lies within Brazilian territory (Hussein, 2018).

Finally, the production of scale of LPRB and GAS comply with the shifting dynamics of territorialisation and development facilitated by the five states over time, such as border demarcation, internal and international trade, agriculture, industrialization, urbanization, environmental conservation, etc. The outcomes of those territorial dynamics are represented by different kinds of infrastructures - ports, dams, reservoirs, etc. - some of which are complementary and some contradictory. Therefore, the result is the aggregation of scales organized by many social actors and interests on the uses of water. Spatial position is a fundamental asset during the construction of environmental governance scales; it guarantees 
access and allocation of natural resources; moreover, it determines the conditions to propose new issues at stake and new directions on foreign environmental politics.

\section{CONCLUSION}

This article examined the production of scale and the different techniques to shape hydropolitical dynamics in South America. The production of scale is an innovative theoretical approach to assess South American hydropolitics and builds on existing institutional and legal analysis and research in the region. The analysis of both hydropolitical trajectories within South American foreign policies, mainly during the twentieth century, shows the production of distinct scales, such as the river basin and aquifer system. Although not every transboundary issue encompassed all riparian countries or all of the river basin, the institutional arrangements were framed by a main scale, where the social actors directed their actions towards water. In addition to national policies, transnational funding banks, regional economic alliances, NGOs, and epistemic communities also compose the entanglement of different actors. Therefore, an array of different scales interacting throughout the river basin and the aquifer system is observed vis-à-vis transboundary waters, where the politics of scale, politics of place, and politics of position are all present.

Along the timeline of hydropolitical interactions, different actors and scales were more relevant, depending on the political goals of the moment. In LPRB, when developing industrialization, urbanization and strengthening national powers were at stake, hydropolitics were regarded as a matter of national importance with the support of international banks to fund the hydraulic mission. Therefore, establishing the terms of ruling the transboundary LPRB was a sovereign issue, shaped by Brazilian regional influence over its neighbours. Also in the GAS case, Brazil exerted its hegemony commanding the negotiations of the GAS Agreement and shaping the terms of the agreement. 
During the advent of regional integration projects, with the creation of MERCOSUR, La Plata and Guarani once again became an infrastructural asset to support transport integration and a reliable resource of water to develop agriculture and industry in the Southern Cone. Currently, this regional bloc has a limited role to play in fostering cooperation among the signatory states because of its decreasing participation on trade and economic negotiations. It is not surprising then that there was disappointment over the lack of success of the waterway project and the ratification of the Guarani Aquifer Agreement. Nevertheless, river basin institutional arrangements, like CIC Plata and FONPLATA, endured as spheres of water governance and dialogue at the transnational political scale that provide access to international funding in a moment of increasing environmental concern.

Another process of scaling hydropolitics is the production of local scale and the use of the nested structure at LPRB. Stemming from climate change uncertainties, rising concerns about the water crisis and environmental disputes along transboundary rivers, sub-basins have been adopted as a salient scale for hydropolitics within La Plata. Fostering cooperative initiatives in sub-catchments is foreseen in the La Plata treaty and in the Framework Program; given regional, ecological and social diversity. This possibility has been gaining momentum with support from international NGOs, awareness of local ecological and social water needs and increased participation of border region populations in environmental governance. This downward rescaling can provide a new opportunity to improve local participation in environmental policy making, establishing a new interaction between traditions of transnational hydropolitics and local initiatives.

Finally, the production of scales demonstrated to be a fruitful theoretical approach to assess hydropolitics in South America. On the one hand, regarding transboundary surface water it is observed a regional to local scalar approach within La Plata. When national sovereign interests were at stake, Brazil used its power and influence to accommodate 
Argentinian and Paraguayan demands to legitimate LPRB as a spatial scale and ratify the La Plata treaty. At that moment, the river basin was the scalar structure used to attune disparate regional geopolitics. When regional disputes were settled and the hydrologic mission was an ongoing process, tensions arose in particular points along the main rivers where big dams were built. At this point, specific technical and diplomatic tools were created to regulate river run-off and deal with mistrust among riparian countries. Currently, new environmental themes are arising and demanding more local, devolved and specific actions. As a result of the uncertain consequences of climate change, studies have been undertaken in order to assess vulnerable places and actions that must be taken.

The GAS hydropolitical trajectory showed a distinct scalar path, going from local governance actions towards a regional scalar approach, which is currently still being constructed. The GAS case showed the construction of scale from a local scale - when it was believed that the GAS water resources were not all connected in a united system, to a regional scale - when the epistemic community showed that it was the case of a system, to a local scale - when the local management as pilot projects of the GAS projects developed, to a regional scale through the establishment of the not yet enforced 2010 GAS agreement.

Scalar production in South American hydropolitics is an evolving process where multiple social actors are engaged. New scales must be produced with the overlapping of surface and groundwater users and new models of governance still need to be created to cope with increasing pressures on both systems. Connections between the surface run-off and the aquifer have shown how a joint management of LPRB and GAS ought to be a fruitful project in the future. Nevertheless, more studies must to be done in order understand the multiple scalar structures in South American hydropolitics. 


\section{REFERENCES}

Allan, T. (2001). The Middle East Water Question: Hydropolitics and the Global Economy London and New York, I.B. Tauris.

Amore, L. (2011). The Guarani Aquifer: from knowledge to water management. International Journal of Water Management. 27: 3, 463-476.

Bakker, K. (2003). "A political ecology of water privatization." Studies in political ecology 70: 35-58.

Bandeira, L. A. M. (2012). A expansão do Brasil e a formação dos Estados na bacia do Prata: Argentina, Uruguai e Paraguai (da colonização à guerra da Tríplice Aliança. Rio de Janeiro, Civilização brasileira.

Barrow, C. (1998). "River basin development planning and management: a critical review." World development 26(1): 171-186.

Biswas, A. K. (2011). "Transboundary water management in Latin America: personal reflections." International Journal of Water Resources Development 27(3): 423-429.

Blanco, L. F. (2012) O novo acordo Brasil-Paraguai e a renegociacao do tratado de Itaipu: enfim uma postura de lideranca sub-regional? Konrad Adenauer Stiftung Brazil. Retrieved in 31 July 2015, from http://www.kas.de/brasilien/pt/publications/17309/.

Brenner, N. (2001). "The limits to scale? Methodological reflections on scalar structuration." Progress in human geography 25(4): 591-614.

Brown, J. C. and M. Purcell (2005). "There's nothing inherent about scale: political ecology, the local trap, and the politics of development in the Brazilian Amazon." Geoforum 36: 607-624.

Camdessus, M., et al. (2005). Água: oito milhões de mortos por ano. Um escândalo mundial. Rio de Janeiro, Bertrand Brasil.

Candeas, A. (2010). A integração Brasil-Argentina. História de uma ideia na "visão do outro". Brasilia, FUNAG.

Cash, D., et al. (2006). "Scale and cross-scale dynamics: governance and information in a multilevel world." Ecology and society 11(2): 18.

Cassuto, D.N. and Sampaio, R.S. (2013). Hard, soft \& uncertain: the Guarani Aquifer and the challenges of transboundary groundwater. Colo. J. Int'I Envtl. L. \& Pol'y 24: 1.

Castillo, L. (2011). "The La Plata basin system against the background of other basin organizations." International Journal of Water Resources Development 27(3): 511-537.

Cibim, J. C. (2012) O desafio da governança nas bacias hidrográficas transfronteiriças internacionais: um ollhar sobre a bacia do rio da Prata. (PhD). Programa de pós-graduação em ciência ambiental, Universidade de São Paulo, São Paulo. 
CIC (2011a). Programa para la gestión sostenible de los recursos hídricos de la Cuenca del Plata, en relación con los efectos de la variabilidad y el cambio climático. Buenos Aires: Departamento de desarrollo sostenible de la Organización de los Estados Americanos - OEA.

CIC (2011b). Documento 1 para la reunión de grupos temáticos - El proyecto. CIC.

Cohen, A. (2015) Nature's scales? watersheds as a link between water governance and the politics of scale. In: Norman, E. (org.) Negotiating water governance: why the politics of scale matter. Farnham, Ashgate,

Cohen, A. and S. Davidson (2011). "The Watershed Approach: Challenges, Antecedents, and the Transition from Technical Tool to Governance Unit." Water Alternatives 4(1): 1-14.

Cohen, A. and J. McCarthy (2014). "Reviewing rescaling: Strengthening the case for environmental considerations." Progress in human geography 39(1): 3-25.

Cook, C. and K. Bakker (2013). Debating the concept of water security. Water security: principles, perspectives and practices. B. Lankford, K. Bakker, M. Zeitoun and D. Conway. New York and London, Routledge.

Dalby, S. (2009). Security and environmental change. Cambridge and Malden, MA, Polity press

Davidson, S. and R. d. Loe (2014). "Watershed Governance: Transcending Boundaries." Water Alternatives 7(2): 367-387.

Dettoni, J. (2013). Time for Brazil and Paraguay to ratify the Guarani aquifer agreement. BNamericas 4 January 2013.

Earle, A., et al. (2010). Introduction: setting the scene for transboundary water management approaches. Transboundary water management: principles and practice. A. Earle, A. Jagerskog and J. Ojendal. London and Washington D.C., Earthscan.

Elhance, A. (1999). Hydropolitics in the $3^{\circ}$ world: conflict and cooperation in international river basins. Washington D.C., United States institute of peace press.

Ferres, V. P. (2004). "A solucao do conflito de Itaipu como inicio da cooperacao politica argentinobrasileira na decade de 80." Projeto historia 29(2): 661-672.

Forman, R. (1995). Land mosaics: the ecology of landscapes and regions. Cambridge, Cambridge university press.

Ghiotti, S. (2006). "Les territoires de l'eau et la decentralisation. La gouvernance de bassin versant ou les limites d'une évidence." Développement durable et territoires Dossier 6.

Gibson, C., et al. (2000). "The concept of scale and the human dimension of global change: a survey." Ecological economics 32: 217-239.

Gilman, P., et al. (2008). "Whiter La Plata? Assessing the state of transboundary water resource cooperation in the basin." Natural resources forum 32: 203-214. 
Giordano, M., et al. (2002). "The geography of water conflict and cooperation: internal pressures and international manifestations." The geographical journal 168(293-312).

Gleick, P. (1993). "Water and conflict: fresh water resources and international security." International Security 18(1): 79-112.

Gleick, P. (2000). "The changing water paradigm: a look at twenty-first century water resources development." Water International 25(1): 127-138.

Gómez-Mera, L. (2013). Power and regionalism in Latin America: The politics of Mercosur. University of Notre Dame Press.

Harvey, D. (1968). "Pattern, process, and the scale problem in geographical research." Transactions of the Institute of the British Geographers 45: 71-78.

Harvey, D. (1996). Justice, nature, and the geography of difference. Cambridge, Oxford, Blackwell.

Herod, A. (2011). Scale. Abingdon, Routledge.

Homer-Dixon, T. (1999). Environment, Scarcity, and Violence. Princeton, Princeton University Press.

Howitt, R. (1993). "“A world in a grain of sand": towards a reconceptualization of geographical scale.

." Australian Geographer 24(1): 33-44.

Howitt, R. (1998). "Scale as relation: musical metaphors of geographical scale." Area 30(1): 49-58.

Howitt, R. (2002). "Scale and the other: Levinas and geography." Geoforum 33: 299-313

Hussein, H. (2016). Hydropolitical dynamics and groundwater governance in the case of the Guarani Aquifer. in Sindico F. and Manganelli, Groundwater Governance: Drawing Connections between Sciences, Knowledge, and Policy-making, SCELG, 4/2016, 2016, University of Strathclyde; Glasgow.

Hussein, H. (2018), The Guarani Aquifer System, highly present but not high profile: A hydropolitical analysis of transboundary groundwater governance", Environmental Science and Policy, Vol. 83, 5462.

Jarvis, $T$ et al (2005) International borders, ground water flow, and hydroschizophrenia. Groundwater. 43:5, 764-770.

Kaplan, R. (1994). "The coming anarchy." The Atlantic February.

Klare, M. (2001). Resource Wars: the new landscape of global conflict. New York, Henry Hold and Company.

Lacoste, Y. (1988). A geografia, isso serve, em primeiro lugar, para fazer a guerra. Sao Paulo, Papirus.

Lankford, B. and N. Hepworth (2010). "The cathedral and the bazaar: monocentric and polycentric river basin management." Water Alternatives 3(1): 82-101.

Lebel, L., et al. (2005). "The politics of scale, position, and place in the governance of water resources in the Mekong region." Ecology and society 10(2): 18. 
Lehner, B., et al. (2011). "High-resolution mapping of the world's reservoirs and dams for sustainable river-flow management." Frontiers in Ecology and the Environment 9(9): 494-502.

Linton, J., (2010). What is water?: the history of a modern abstraction. Vancouver: UBC Press.

Marston, S., et al. (2005). "Human geography without scale." Transactions of the Institute of British Geographers 30: 416-432.

Mason, M. and M. Zeitoun (2013). "Questioning environmental security." The geographical journal 179(4): 294-297.

McMaster, R. and E. Sheppard (2004). Introduction: Scale and geographic inquiry. Scale and geographic inquiry: nature, society, and method. E. Sheppard and R. McMaster. Oxford Blackwell: 122.

Mirumachi, N. (2013). "Securitising shared waters: an analysis of the hydropolitical context of the Tanakpur Barrage project between Nepal and India." The geographical journal 179(4): 309-319.

Mirumachi, N. (2015). Transboundary water politics in the developing world. Milton Park, Oxon, United Kingdon; New York, United States, Routledge.

Molle, F., et al. (2009). "Hydraulic Bureaucracies and the Hydraulic Mission: Flows of Water, Flows of Power." Water Alternatives 2(3): 328-349.

Molle, F. and P. Wester (2009). River basin trajectories : societies, environments and development. Wallingford, Oxfordshire ; Cambridge, MA, CABI ; [Battaramulla, LK] : International Water Management Institute.

Molle, F. (2015) Introduction to part 1. In: Norman, E. (org.) Negotiating water governance: why the politics of scale matter. Farnham, Ashgate,

Moss, T. and J. Newig (2010). "Multi-level water governance and problems of scale: setting the stage for a broader debate." Environmental Management 46: 1-6.

Norman, E. et al. (2015). Introduction: why the politics of scale matter in the governance of water. In: Norman, E. (org.) Negotiating water governance: why the politics of scale matter. Farnham, Ashgate,

Norman, E. S. and K. Bakker (2015). "Do good fences make good neighbours? Canada-United States transboundary water governance, the Boundary Waters Treaty, and twenty-first-centuty challenges." Water International 40(1): 199-213.

Oliveira, M. G. (2012). As cidades-gêmeas Ponta Porá - Pedro Juan Caballero e Foz do Iguaçu - Ciudad del Este diante da des-articulação regional sul-americana. Departamento de Geografia. Rio de Janeiro, Universidade Federal do Rio de Janeiro. Doutorado.

Patole, M. (2015). Transboundary Groundwater Management: The Guarani Aquifer System Conference paper: World Water Congress XV, Edinburgh, Scotland. 
Planalto (2013). "Dilma inaugura linha de 500 KV entre Itaipu e Villa Hayes." Retrieved 28 April, 2015, from http://www2.planalto.gov.br/centrais-de-conteudos/videos/dilma-inaugura-linha-de500-kv-entre-itaipu-e-villa-hayes.

Pochat, V. (2011). "International agreements, institutions and projects in La Plata basin." International Journal of Water Resources Development 27(3): 497-510.

Popescu, l., et al. (2012). "Assessing residual hydropower potential of the La Plata Basin accounting for future user demands." Hydrology and Earth System Sciences 16: 2813-2823.

Puiggrós, R. (2006). Historia económica del Río de la Plata. Buenos Aires, Retorica Ediciones e Altamira.

Quaraí (2014). 10 Plano de gestão - Comitê de Gerenciamento das Águas Estaduais da Bacia do Rio Quaraí, Manuscript.

Queiroz, F. A. d. (2012). Hidropolítica e segurança: as bacias platina e amazônica em perspectiva comparada. Brasília, FUNAG.

Queiroz, F. A. d. (2012). Hydropolitics in South American International Relations: A Perspective on Water Governance at the Prata Basin. New Security Frontiers: Critical Energy and the Resource Challenge. S. F. Krishna-Hensel. Surrey, England; Burlington, USA, Ashgate Publising: 139-172.

Reed, M. and S. Bruyneel (2010). "Rescaling environmental governance, rethinking the state: A three-dimensional review." Progress in human geography 34(5): 646-653.

Sant'Anna, F. (2015) A integração regional na América Latina e o uso compartilhado das bacias transfronteiriças: as bacias do Prata e do Amazonas. WATERLAT-GOBACIT NETWORK WORKING PAPERS, v. 2, p. 37-54, 2015

Sayre, N. (2005). "Ecological and geographical scale: parallels and potential for integration." Progress in human geography 29(3): 276-290.

Sayre, N. (2009). Scale. A companion to environmental geography. N. Castree, D. Demeritt, D. Liverman and B. Roads. Malden, MA and Oxford, Blackwell: 95-108.

Silva, L.P. (2017). Hidropolítica sul-americana e a Bacia do Prata: o lugar das sub-bacias em zonas de fronteira internacional. (PhD) Programa de pós-graduação em geografia, UFRJ, Brazil.

Sneddon, C. (2002). "Water conflicts and river basins: the contradictions of comanagement and scale in northeast Thailand." Society and natural resources: an international journal 15(8): 725-741.

Sneddon, C. and C. Fox (2006). "Rethinking transboundar waters: a critical hydropolitics of the Mekong basin." Political Geography 25: 181-202.

Swyngedouw, E. (1999). "Modernity and hybridity: nature, regeneracionismo, and the production of Spanish waterscape, 1890-1930." Annals of the Association of American Geographers 89(3): 443465.

Swyngedouw, E. (2007). "Technonatural revolutions: the scalar politics of Franco's hydro-social dream for Spain, 1938-1975." Transactions of the institute of british geographers 32: 9-28. 
Taylor, P. (1982). "A materialist framework for political geography." Transactions of the Institute of British Geographers 7(1): 15-34.

Tucci, C. (2004). Visão dos Recursos Hídricos da bacia do Rio da Prata - Visão regional - Volume I. C. GEF, PNUMA, OEA, CIC-Plata.

Uitto, J. and A. Wolf (2002). "Water wars? Geographical perspectives: introduction." The geographical journal 168(4): 289-292.

UN-Water (2008). Transboundary waters: sharing benefits, sharing responsabilities, United Nations.

Veja. (1977). A sofrida procura da paz. Revista Veja Rio de Janeiro, Abril. 464: 20.

Villar, P.C. (2016). International cooperation on transboundary aquifers in South America and the Guarani Aquifer case. Revista Brasileira de Política Internacional 59(1).

Villar, P.C. and Ribeiro, W.C. (2011). The Agreement on the Guarani Aquifer: a new paradigm for transboundary groundwater management? Water international 36(5): 646-660.

Villar, P.C; Ribeiro, W. C.; Sant'Anna, F. (2018) Transboundary governance in the La Plata River basin: status and prospects. Water International, 43:7, 978-995, DOI: 10.1080/02508060.2018.1490879

Walter, M. (2010). Managing Transboundary Aquifers: Lessons from the Field. Paper read at Research paper collection, International Conference "Transboundary Aquifers: Challenges and New Directions (ISARM).

Walter, M. (2015). The Invention of the Guarani Aquifer System. ReVista (Cambridge) 14(3): 23.

Wiens, J. (1989). "Spatial scaling in ecology." Functional ecology 3: 385-397.

Wolf, A. (1998). "Conflict and cooperation along international waterways." Water Policy 1: 251-265.

World Bank. (2002). Environmental Protection and Sustainable Development of the Guarani Aquifer System: Project Appraisal Document No. 23490-LAC.

Zeitoun, M. and N. Mirumachi (2008). "Transboundary water interaction I: reconsidering conflict and cooperation." International Environmental Agreements 8: 296-316.

Zeitoun, M., et al. (2011). "Transboundary water interaction II: the influence of 'soft' power." International Environmental Agreements 11: 159-178.

Zeitoun, M. and J. Warner (2006). "Hydro-hegemony - a framework for analysis of trans-boundary water conflicts." Water Policy 8: 435-460.

Zinzani, A., \& Menga, F. (2017). The Circle of Hydro-Hegemony between riparian states, development policies and borderlands: Evidence from the Talas waterscape (KyrgyzstanKazakhstan). Geoforum, 85, 112-121.

Zugaib, E. (2007). A hidrovia Paraguai-Paraná. Brasília, Funag. 